\title{
Effects of Role-Play on Indonesian Junior High School Students' Speaking Skills: A Classroom Action Research Study
}

\author{
Yoniswan $^{l}$ \\ ${ }^{1}$ Corresponding author, SMP N 24 Bintan, Kepulauan Riau, Indonesia; \\ yoniswan1@gmail.com
}

\begin{abstract}
The purpose of this study was to implement Role-Play method in improving English speaking abilities. This research is a classroom action research consisting of two cycles, each cycle consisting of planning, implementation, observation and reflection. The study was conducted in eight grade semester I of 2016/2017 academic year at SMP Negeri 17 Bintan with a total of 34 research subjects. The data collection methods used in this study are performance tests and observations. Quantitative method is used as data analysis. The results showed an increase in English speaking skills through Role Play method, in the first cycle with an average score of 63.06 percentage of completeness $17.65 \%$, increased in the second cycle with an average score of 75.65 percentage of completeness $85.29 \%$. It was concluded that Role-Play method can improve English speaking skills.
\end{abstract}

Keywords: Classroom Action Research, Role-Play, Speaking Skills

\section{Introduction}

Speaking skills are the core of the language learning process at school, because with learning to speak students can communicate inside and outside the classroom in accordance with the development of their souls (Galda in Supriyadi, 2005). Learning speaking skills is important to teach because with these skills a student will be able to develop the ability to think, read, write, and listen. The ability to think will be trained when they organize, conceptualize, and simplify thoughts, feelings, and ideas to others verbally.

Speaking skills (speaking skills) in English according to Teguh Budiharso (2004: 68), is a skill for someone to convey their desires and thoughts to anyone through oral, however, speaking skills are difficult to develop if not trained continuously and can be done with classmates, English teachers, or other teachers who can speak English. The aim is to facilitate speaking skills, enrich the use of vocabulary, improve the language order, perfect vocabulary words, English sentences, and practice hearing so that it is easy to catch messages from the speaker.

Speaking skills according to Iskandarwassid and Dadang Suhendar (2008: 241), in essence are skills to produce the flow of articulation sound systems to convey the will, needs of feelings, and desires to others. In this case, the completeness of one's utterance is a natural 
requirement that enables it to produce a broad range of articulation sounds, tone pressures, silence, and songwriting. This skill is also based on the confidence to speak naturally, honestly, correctly, and responsibly by eliminating psychological problems such as shame, low self-esteem, tension, heavy tongue, and others.

Based on observations in class VIII semester I of 2016/2017 academic year in SMP N 17 Bintan, students' English speaking skills categorized as low since their scores was only average of 55.88 and the percentage of mastery learning is $8.82 \%$. This average is far below the minimum standard (KKM) of English subjects at SMP Negeri 17 Bintan, which is 72. Only 3 people out of 34 students are able to pass in this English speaking performance. There are several obstacles and conditions encountered including: 1) the teacher has difficulty activating students during the learning process, 2) the learning process is less lively, 3) students are less courageous in expressing opinions, 4) students' answers are less creative because they only mimic the existing examples, 5) students are often wrong in pronunciation, 6) students sometimes busy themselves when the lesson takes place but when asked questions immediately become silent all. This condition causes the learning process of English to not run properly.

To overcome these problems, learning strategy is needed in order to motivate students to be more active, creative, innovative and fun to improve students' English speaking skills. To improve English speaking skills of eighth grade students of SMP Negeri 17 Bintan, improvements were made to the learning process using the Role-play method.

Role-Play is acting according to a predetermined role. According to Sudjana (2009: 89), the Role-play method is a way of teaching by dramatizing the form of behavior in social relationships. This learning strategy is a type of learning method that is complex. Blatner (in Komalasari, 2010: 58) Role-Play learning method explores complex social situations, which emphasize emotional involvement and sensory devices into problem situations encountered. Role-play Method is a method of mastering learning materials through developing the imagination and appreciation of students. The development of imagination and appreciation is done by students playing the role of living figures or inanimate objects. This role-play is generally done by more than one person, it depends on the role played. The importance of role-play was also emphasized by Howell (1992) that students in role-play method "to feel issues, experience tension and conflict and enter into bargaining and cooperation".

The formulation of the problem of this research is whether role-play can improve English speaking skills of Grade VIII students in the first semester of the 2016/2017 academic year at SMP N 17 Bintan. The purpose of the research is to improve students' English speaking skills.

\section{Method}

The research conducted was Classroom Action Research (CAR). The Ministry of Education and Culture (2011: 12) explains the research process carried out in two cycles, each cycle consisting of four stages, namely: (1) planning, (2) implementation, (3) observation, (4) reflection.

\subsection{Respondents}

This classroom action research was carried out at SMP Negeri 17 Bintan, Bintan Regency, Kepulauan Riau with 20 male and 14 female students as the respondents. 


\subsection{Instruments}

The data collection method uses performance tests and observations. The instrument of collecting data in this study was performance tests and observation sheet. The items in the test are as follow:

\begin{tabular}{|c|c|c|c|}
\hline No & Aspect & Item & Score \\
\hline \multirow{5}{*}{1.} & \multirow{5}{*}{ Pronunciation } & $\begin{array}{l}\text { Easy to understand and has a native } \\
\text { speaker accent }\end{array}$ & 5 \\
\hline & & $\begin{array}{l}\text { Easy to understand even with certain } \\
\text { accents }\end{array}$ & 4 \\
\hline & & $\begin{array}{l}\text { There are pronunciation problems that } \\
\text { make the listener have to concentrate fully } \\
\text { and sometimes there are } \\
\text { misunderstandings }\end{array}$ & 3 \\
\hline & & $\begin{array}{l}\text { Difficult to understand because there are } \\
\text { pronunciation problems, often asked to } \\
\text { repeat }\end{array}$ & 2 \\
\hline & & $\begin{array}{l}\text { The pronunciation problem is serious so it } \\
\text { can't be understood }\end{array}$ & 1 \\
\hline \multirow{5}{*}{2.} & \multirow{5}{*}{ Grammar } & No or few grammatical errors & 5 \\
\hline & & $\begin{array}{l}\text { Sometimes it makes grammatical mistakes } \\
\text { but it doesn't affect the meaning }\end{array}$ & 4 \\
\hline & & $\begin{array}{l}\text { Often make grammatical mistakes that } \\
\text { affect meaning }\end{array}$ & 3 \\
\hline & & $\begin{array}{l}\text { Many grammatical mistakes hinder } \\
\text { meaning and often rearrange sentences }\end{array}$ & 2 \\
\hline & & $\begin{array}{l}\text { Grammatical errors are so severe that they } \\
\text { are difficult to understand }\end{array}$ & 1 \\
\hline \multirow{5}{*}{3.} & \multirow{5}{*}{ Vocabulary } & $\begin{array}{l}\text { Use vocabulary with phrases like native } \\
\text { speakers }\end{array}$ & 5 \\
\hline & & Sometimes it uses incorrect vocabulary & 4 \\
\hline & & $\begin{array}{l}\text { Often using inappropriate vocabulary, } \\
\text { conversations become limited because of } \\
\text { limited vocabulary }\end{array}$ & 3 \\
\hline & & $\begin{array}{l}\text { Using vocabulary incorrectly and } \\
\text { vocabulary is limited so it is difficult to } \\
\text { understand }\end{array}$ & 2 \\
\hline & & $\begin{array}{l}\text { Vocabulary is so limited that conversation } \\
\text { is not possible }\end{array}$ & 1 \\
\hline \multirow{3}{*}{4.} & \multirow{3}{*}{ Fluency } & Smoothly like a native speaker & 5 \\
\hline & & $\begin{array}{l}\text { Smoothness seems a little disturbed by } \\
\text { language problems }\end{array}$ & 4 \\
\hline & & $\begin{array}{l}\text { Fluency is somewhat disturbed by } \\
\text { language problems }\end{array}$ & 3 \\
\hline
\end{tabular}




\begin{tabular}{lllc}
\hline No & Aspect & \multicolumn{1}{c}{ Item } & Score \\
\hline & $\begin{array}{l}\text { Often hesitant and stopped because of } \\
\text { language limitations }\end{array}$ & 2 \\
& $\begin{array}{l}\text { Talk is intermittent and paused so that } \\
\text { conversation is not possible }\end{array}$ & 1 \\
\hline \multirow{5}{*}{ Understanding } & $\begin{array}{l}\text { Understand all without experiencing } \\
\text { difficulties }\end{array}$ & 5 \\
& $\begin{array}{l}\text { Understanding almost everything, } \\
\text { although there are repetitions in certain }\end{array}$ & 4 \\
& $\begin{array}{l}\text { Understand most of what is said when } \\
\text { speaking is somewhat slowed despite }\end{array}$ & 3 \\
& repetition & \\
\hline & $\begin{array}{l}\text { It's hard to follow what is said } \\
\text { Can not understand even a simple } \\
\text { conversation }\end{array}$ &
\end{tabular}

The observation sheet is as follow:

\begin{tabular}{|c|l|r|r|r|r|r|r|}
\hline \multirow{2}{*}{ No } & \multicolumn{1}{|c|}{ Aspect } & \multicolumn{5}{|c|}{ Score } & Total \\
\cline { 2 - 7 } & & 5 & 4 & 3 & 2 & 1 & Score \\
\hline 1. & Pronunciation & & & & & & \\
\hline 2. & Grammar & & & & & & \\
\hline 3. & Vocabulary & & & & & & \\
\hline 4. & Fluency & & & & & & \\
\hline 5. & Understanding & & & & & & \\
\hline \multicolumn{7}{|l|}{ Average: }
\end{tabular}

Score $=\frac{\text { Total Score }}{\text { Maximum Total score }} \times 100$

\subsection{Data Analysis}

The data analysis method used is a quantitative analysis method. Quantitative methods are used to calculate the mean, median, mode, make class intervals and make presentations in tables and figures.

To simplify the interpreted quantitative data, it was used scoring method. There were two types of scoring in this study. They were: (1) student's score, (2) average score.

\section{Finding and Discussion}

English learning is not optimal, learning activities are still teacher-centre. The teacher finds difficult to manage students when learning takes place. The teacher has not used an innovative learning model, so students are less motivated in learning. Teachers do not involve students in learning activities and consequently students become passive in learning activities. This causes the learning objectives to make all students active in speaking skills not achieved and the expected results are not optimal. The pre-cycle test results can be found in the following table. 
Table 1. Students' speaking score in pre-cycle

\begin{tabular}{lc}
\hline Mean & 55,88 \\
\hline Passed Minimal Score & 72 \\
\hline Not Passed students & 31 \\
\hline Passed Students & 3 \\
\hline Passed percentage & $8,82 \%$ \\
\hline
\end{tabular}

\subsection{Cycle 1}

\section{Planning}

Planning cycle I is, setting the time for conducting research, preparing lesson plans using the Role-play method, preparing learning resources and tools, namely the Role-play script, student observation sheets and assessment instruments in the form of performance tests, and carrying out simulation of Role-play activities.

\section{Implementation}

Implementation of the first cycle of action in the form of the implementation of learning English speaking skills by applying the steps of the Role-play method.

In this initial activity the researcher greets, checks student attendance, conditions students to be ready to follow the lesson, conveys topics to be learned, provides motivation, conveys learning objectives, and explains the steps of learning by applying the Role-play method.

The core activities carried out are first, the researcher determines who will play the role and classifies it as a group of role players, then the researcher discusses what material will be played by each player. Second, the researcher appoints several students as observers and groups them as observers. Third, researchers discuss with students how that role will be played. What are the requirements needed to play a role. Fourth, students begin role play, role play is carried out in earnest. Fifth, students in the observer group discuss the questions given by researchers in accordance with the role play that has been played by students from the role-play group and conduct an evaluation by presenting the results of the discussion.

In the closing activity the researcher invited students to share experiences about the theme of role play that had been done and continued with making conclusions. Then the researcher closed the meeting with a closing remark.

\section{Observations}

Observers or data collection is done by researchers after the learning process in three meetings by giving a test of speaking skills. The results of data collection in the first cycle obtained an average of 63.06 and the percentage of mastery learning $17.65 \%$.

\section{Reflection}

Students' English speaking skills in presenting the data above indicate that the average value of students has reached 63.06 with a percentage of completeness of $17.65 \%$. There is an increase in pre-cycle speaking skills. When compared with the indicators of the success of the study, which is an average of 72 with a minimum percentage of completeness of $80 \%$. Some things that are affected during the process of action as a cause of the lack of success of the action, namely, limited time, students are less open and communicating with researchers 
when facing difficulties, students are embarrassed and lack of confidence when appearing to play roles and communication between researchers and students less communicative so that students still tend to be less enthusiastic in participating in learning activities.

\subsection{Cycle 2}

\section{Planning}

In principle, planning activities for cycle II are not much different from planning for cycle I. Cycle II is an effort to improve and perfect the actions of cycle I. All stages are carried out the same, only that in cycle II there are a number of things that need to be emphasized and added in the implementation of learning in the classroom, namely: First, before carrying out the action cycle II, students are more emphasized again about the steps of Role-play learning that will be applied. Second, for the problem of time constraints, students are required to be more serious and focus in the learning process so that time can be utilized to the maximum. Third, train students to communicate and cooperate with others so that students dare to express opinions without shame, and researchers will emphasize students to actively ask questions that have not been understood. Fourth, students are required to play their roles maximally. Arranging several plans that will be carried out, including: $R e-$ checking the lesson plan (RPP) that has been planned and prepared. Re-examine the sequence designed from the initial activity to the final activity. Efficient time is not right in the first cycle. Prepare learning resources and tools that will be used in every time the action is the Role-play script, student observation sheets and assessment instruments in the form of performance tests (practice).

\section{Implementation}

The process of applying the Role-play method in accordance with the planning that has been made is as follows:

In the initial activity the researcher greets, checks student attendance, conditions students to be ready to take lessons, conveys topics to be learned, provides motivation, conveys learning objectives, and explains learning steps by applying Role-play methods.

The core activities carried out are first, the researcher determines who will play the role and classifies it as a group of role players, then the researcher discusses what material will be played by each player. Second, the researcher appoints several students as observers and groups them as observers. Third, researchers discuss with students how that role will be played. What are the requirements needed to play a role. Fourth, students begin role play, role play is carried out in earnest. Fifth, students in the observer group discuss the questions given by researchers in accordance with the role play that has been played by students from the role-play group and conduct an evaluation by presenting the results of the discussion.

In the closing activity the researcher invited students to share experiences about the theme of role play that had been done and continued with making conclusions Then the researcher closed the lesson with a closing greeting. 


\section{Observations}

Observers or data collection is done by researchers after the learning process in three meetings by giving a test of speaking skills. The results of data collection in the second cycle obtained an average of 75.65 and the percentage of mastery learning $85.29 \%$.

\section{Reflection}

Deficiencies in the first cycle have been corrected in the second cycle of learning and as a result students are more orderly, conducive, active, able to work well together and improve students' speaking skills.

The increase is shown from the average value of students has reached 75.65 exceeding the KKM determined by the percentage of mastery learning classically by $85.29 \%$. These results prove that the actions or treatments given to students with the Role-play learning method on each English subject matter, have had a meaningful understanding effect on students. The things obtained in cycle II include: student motivation that is seen from the activeness of students in participating in learning is quite increased, students have been active to directly discuss with friends and immediately go to the front of the class, the learning process of students is active and more confident in responding learning.

Through the final reflection in this second cycle, it can be concluded that: With the application of the Role-play learning method, role-play is new to students so that the level of attention, seriousness, responses, and activeness of students has entered a high criterion. This may happen because the current method facilitate students to "practice interpersonal and relational skills as part of the simulation" (Schafer, 2015: 7). The level of understanding of students in accordance with expectations and speaking skills of students increased quite well. Obstacles found in the second cycle are almost not found, even students expect to carry out the same learning with the implementation of classroom action research that begins cycle I and II.

Students' English speaking skills in learning achieved by students are good enough. Learning in the second cycle has increased a lot, although not yet fully. Because of the limitations of this study until the second cycle, the researchers considered learning by applying the Role-play method to improve students' English speaking skills which had been done in two cycles enough to draw final conclusions.

Increasing the value of speaking skills in Pre-Cycle I and Cycle II are as follows:

Table 2. Scores in Pre-Cycle, Cycle 1 and Cycle 2

\begin{tabular}{|c|c|c|c|c|c|c|}
\hline \multirow[b]{2}{*}{ Indicators } & \multicolumn{2}{|c|}{ Pre-cycle } & \multicolumn{2}{|c|}{ cycle I } & \multicolumn{2}{|c|}{ Cycle II } \\
\hline & Average & $\begin{array}{c}\text { \% Passing } \\
\text { Students }\end{array}$ & Average & $\begin{array}{c}\% \text { Passing } \\
\text { Students }\end{array}$ & Average & $\begin{array}{c}\% \text { Passing } \\
\text { Students }\end{array}$ \\
\hline $\begin{array}{l}\text { English Speaking } \\
\text { Skills }\end{array}$ & 55,88 & $8,82 \%$ & 63,06 & $17,65 \%$ & 75,65 & $85,29 \%$ \\
\hline
\end{tabular}


The brief comparison is available as in figure 1.

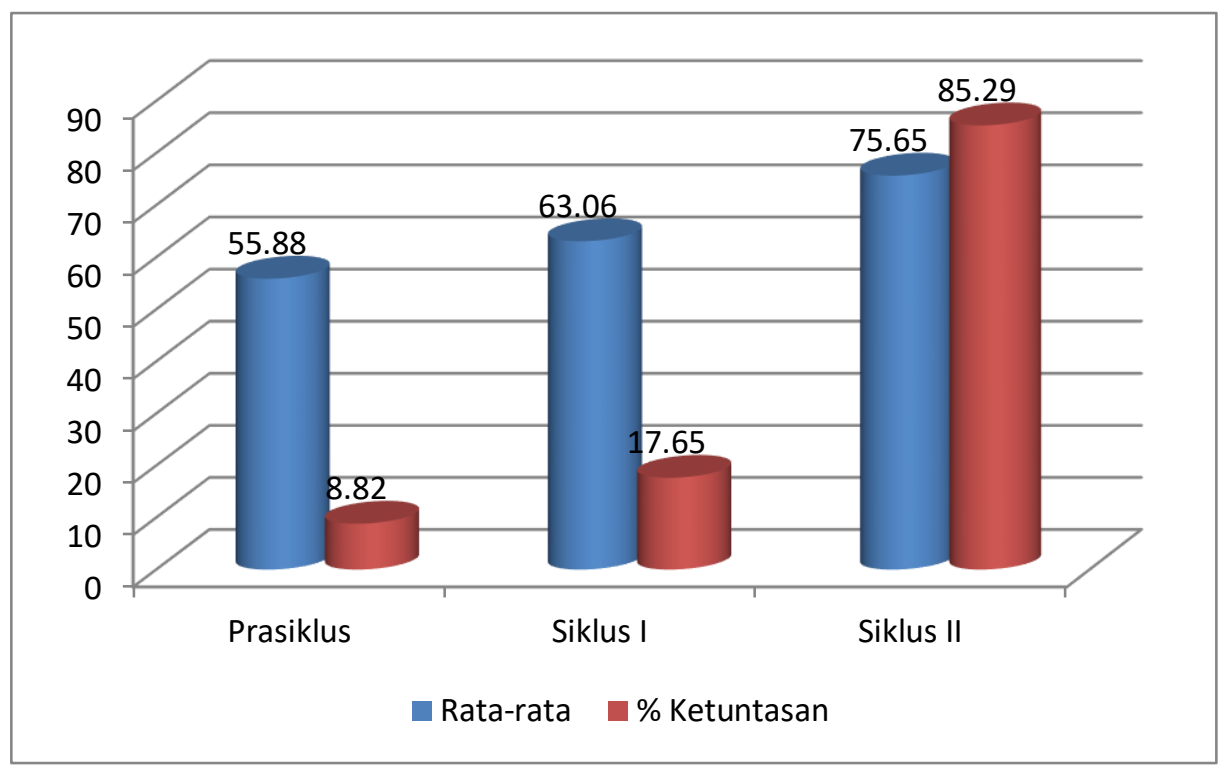

Figure 1. The comparison of all scores in Pre-Cycle, Cycle 1, and Cycle 2

\section{Conclusion}

After learning through the Role-play method, students' English speaking skills have increased. The average value of speaking skills in pre-cycle was 55.88, increased in the cycle to 63.06 and increased again in the second cycle to 75.65. Similarly, an increase in the percentage of students' mastery learning, namely in the pre-cycle $8.82 \%$, in the cycle increased to $17.65 \%$ and in the second cycle increased to $85.29 \%$. The results obtained are as expected so that they can provide answers to the formulation of the problem and the purpose of this study.

Based on the results obtained through the application of the Role-play method, it is recommended for teachers to apply the Role-play method in teaching and learning activities, especially in learning speaking skills, because the role-play method is more effective and efficient compared to conventional methods which are generally still often used in learning to speak. Students should understand that speaking skills are an important thing that must be mastered, for that students need to follow learning to speak with full sincerity so that students have good speaking skills. With the Role-play method, students should be able to use it well to work together in a group, both in discussion and role-play so that the results can be optimized. Subsequent researchers, it is advisable to examine the same topic to examine parts that were not examined. 


\section{References}

Budiharso, Teguh. (2004). Prinsip dan Strategi Pengajaran Bahasa. Surabaya: Lutfiansah Mediatama.

Howell, Jude. Using Role Play as a Teaching Method. Teaching Public Administration, 12 (1): 69-75. https://doi.org/10.1177/014473949201200109

Hughes, R. (2002). Teaching and researching speaking. UK: Pearson Education Limited.

Iskandarwassid and Sunendar, D. (2008.) Strategi Pembelajaran Bahasa. Bandung:Remaja Rosdakarya.

Kemendikbud. (2011). Membimbing Guru dalam Penelitian Tindakan Kelas. Jakarta: Pusat Pengembangan Tenaga Kependidikan Badan Pengembangan Sumber Daya Manusia Pendidikan dan Menjaminan Mutu Pendidikan.

Komalasari, Kokom. (2010). Pembelajaran Kontekstual Konsep Dan Aplikasi. Bandung: Refika Aditama.

Redmond, M.V. \& Vrchota, D. (2007). Everyday Public Speaking. England: Pearson Education

Schafer, J.G. (2015). Making role-Playing Real. Teaching Public Administration, 34 (2): 150-158. https://doi.org/10.1177/0144739415611215

Suadi. (2020). Improving Students’ English Speaking Skill By Using Their Speaking Video Recording. SALEE: Study of Applied Linguistics and English Education. 1(1), 1-10.

Sudjana, Nana. (2009). Dasar-dasar Prosedur Belajar Mengajar. Bandung: Sinar Baru Algesindo.

Supriyadi, et al. (2005). Pendidikan Bahasa Indonesia 2. Jakarta: Depdikbud.

Thornbury, S. (2005). How to teach speaking. England: Pearson Education limited. 